\title{
Report of the first case of myxoid liposarcoma in Colombia: a rare tumor
}

\author{
Luz Fernanda Sua, MD*, Nhora María Silva, MD*
}

\section{SUMMARY}

Introduction: Primary esophageal myxoid liposarcoma is exceedingly rare. Sarcomas make up $1 \%$ of esophageal malignant tumors. There are only five (5) cases reported with this histological variant (myxoid) in previous literature. In Colombia, this is the first case reported and the sixth in the world.

Objective: To report the first case in Colombia of myxoid liposarcoma of the esophagus with clinical, radiographic images, histology, surgical and to describe difficulties in the diagnosis.

Methodology: We reviewed the clinical history of a 28-year old male patient. He was admitted to Hospital Universitario del Valle in Cali, Colombia with a clinical history of dysphagia, weight loss, and excessive salivation.

The initial examination (esophagogram, cervical CAT scan and endoscopy) demonstrated a mass that was reported as a fibrovascular polyp. The finding of the pathological diagnosis was myxoid liposarcoma.

Conclusions: The rarity of this condition recommends report of its detailed description. The myxoid liposarcoma of the esophagus can be diagnosed if a patient has a history of a slow-growing esophageal mass with a low tumor density in computed tomography in combination with surgical resection and histological examination.

Keywords: Esophageal liposarcoma; Myxoid liposarcoma; Esophageal polyp; Fibrovascular esophageal polyp.

Informe del primer caso de liposarcoma mixoide en Colombia: un tumor raro

\section{RESUMEN}

Introducción: El liposarcoma mixoide es una neoplasia maligna del mesénquima con una presentación muy rara en esófago. Los sarcomas representan 1\% de los tumores esofágicos malignos, y este tipo histológico es el menos frecuente. En la actualidad, se encuentran informes en la literatura de cinco (5) casos de esta variante histológica en el esófago. En Colombia, es el primer caso encontrado y el sexto $\left(6^{\circ}\right)$ a nivel mundial.

Objetivo: Presentar el primer caso en Colombia de un liposarcoma mixoide en el esófago, sus características clínicas, imagenológicas, histología, manejo quirúrgico y las dificultades en su diagnóstico.

Metodología: Se revisó la historia clínica de un paciente masculino de 28 años que ingresa por urgencias al Hospital Universitario del Valle en Cali, Colombia, con historia de disfagia, pérdida de peso y sialorrea. Los estudios imagenológicos como esofagograma, escanografía cervical y endoscopia de vías digestivas altas son consistentes con un pólipo esofágico y el manejo quirúrgico consistió en la resección parcial y luego la resección completa de la lesión. El informe histopatológico de la resección parcial comunicó un pólipo fibrovascular y el informe de la resección completa fue de liposarcoma mixoide. Las dificultades diagnósticas que surgieron en este caso se relacionan con otras encontradas en la literatura.

Conclusiones: El liposarcoma mixoide del esófago es una entidad que presenta dificultades en su diagnóstico debido a que la presentación clínica no es específica. Aunque en estos casos las biopsias iniciales pueden suponer lesiones benignas, sólo hasta el procesamiento histológico de todo el espécimen, es posible realizar el diagnóstico de la entidad.

Palabras clave: Liposarcoma esofágico; Liposarcoma mixoide; Pólipo esofágico; Pólipo fibrovascular gigante.

Myxoid liposarcoma is a malignant neoplasia of mesenchymal origin with unusual presentation in the esophagus. Sarcomas represent $1 \%$ of malignant tumors; this being the least frequent histological type that is of difficult clinical, imaging, endoscopic, and histological diagnosis ${ }^{1}$. Currently, there are reports of five cases of

* Resident, Pathological Anatomy and Clinical Pathology, School of Medicine, Faculty of Health, Universidad del Valle, Cali,Colombia.e-mail:lufer24@ hotmail.com e-mail:nhorita13@hotmail.com

Received for publication January 21, 2009 Accepted for publication April 9, 2010 
this histological variant in the esophagus. In Colombia, it is the first reported case until now and the sixth according to world literature.

\section{CLINICAL CASE}

The patient was admitted to our hospital facilities in March 2008, because of symptoms of progressive dysphagia, loss of weight $(20 \mathrm{~kg})$, and esophageal intraluminal mass) with four months of evolution. An esophagogram was performed, revealing a major polypoid lesion in the cervical and thoracic esophagus extending from $\mathrm{C} 7$ level to the carina, which was in endoluminal position(Figure 1). Cervical scanning shows evidence of endoluminal mass image in the lower cervical esophagus and thoracic esophagus (Figure 2).

Upper GI endoscopy reports: Easy passage through the cricopharyngeal and immediately beneath, a grand polypoid lesion is observed $(12 \mathrm{~cm}$ long $\mathrm{x} 2 \mathrm{~cm}$ in diameter), which extends to $32 \mathrm{~cm}$ of the dental arch. The endoscopy concludes with the presence of an esophageal polyp.

Endoscopic partial resection of the lesion is conducted on two opportunities and these are sent to pathological anatomy services, where the histological findings of the two samples reveal: squamous epithelium with surface ulceration in whose stroma there are large vascular lumina with hemorrhagic content. There are stromal areas with mature adipose tissue, collagenized and myxoid foci without atypia and mixed inflammatory infiltrate. Histological conclusion yields: Giant fibrovascular polyp ${ }^{1-2}$ (Figure 3 ).

The patients was programmed for open surgery given that, endoscopically, it was impossible to resacate the lesion. Left cervicotomy was performed with later giant polyp removal $(20 \mathrm{~cm}$ long); the pedicle was found in the upper third, $7 \mathrm{~cm}$ from the dental arch, in addition to purulent fluid $(10 \mathrm{ml})$ and esophageal perforation (Figure 4). Five days after the surgical procedure, the patient presents bleeding through cervicotomy, leading to hypovolemic shock; he is intervened via Vascular raffia procedure. Seven days after this episode, the patient was released from the hospital-once he was able to tolerate oral feeding. The patient was scheduled to post-surgical controls and showed no evidence of recurrence 12 months after surgical treatment.

Macroscopically, a specimen is obtained with polypoid

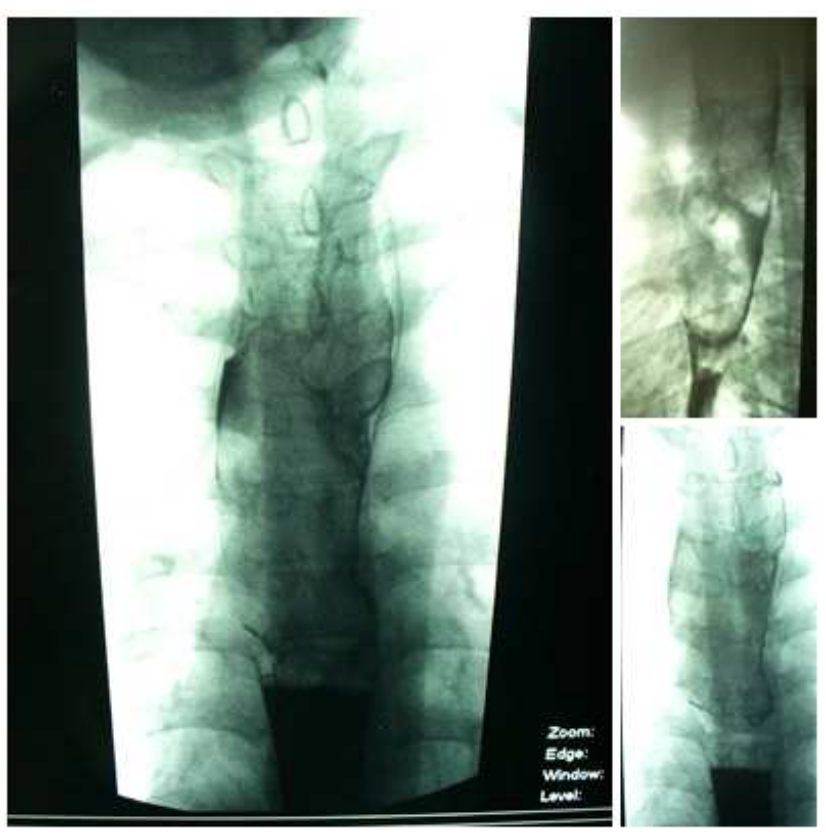

Figure 1. Esophagogram identifying the polypoidtype lesion, localized at the $\mathrm{C} 7$ level and with endoluminal location

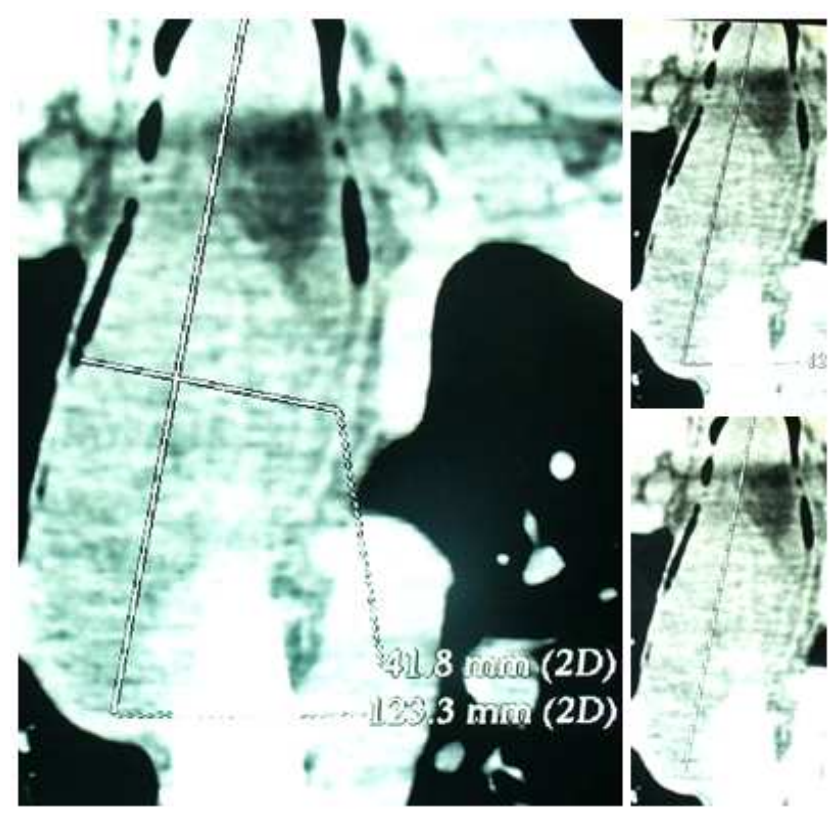

Figure 2. Scan study allows defining a mass of endoluminal localization in the cervical and thoracic esophagus

aspect, measuring $20 \times 6 \times 5 \mathrm{~cm}$, weighing 250 grams, with ulcerated surface at the distal end. Upon cutting, it is of myxoid aspect with adipose foci and whitish compact nodular areas (Figure 5). 


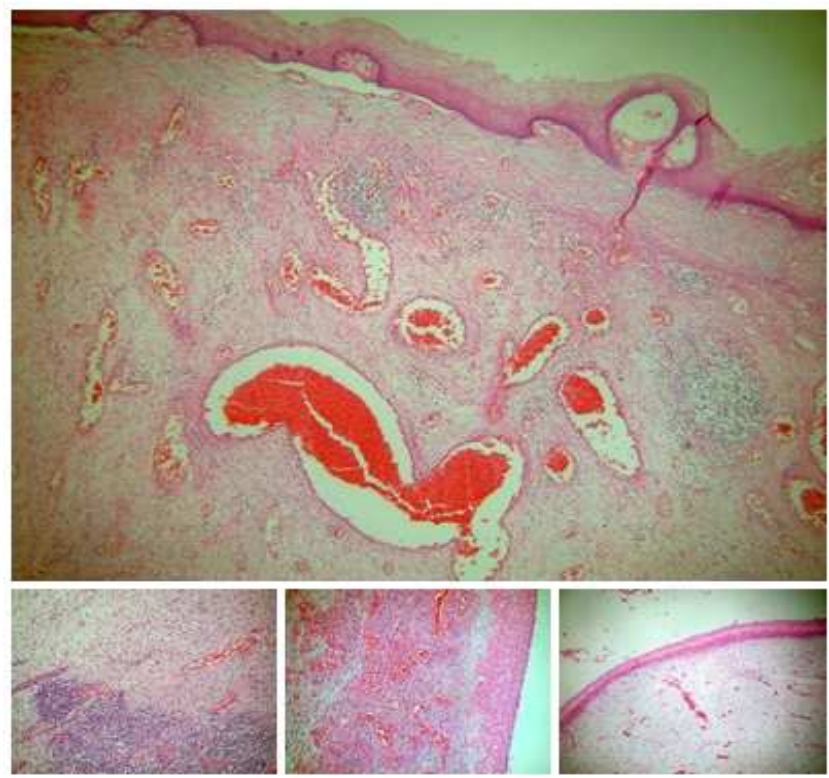

Figure 3. Identifies squamous epithelium and presence of large vascular lumina with haematic content. The stroma is collagenized and myxoid without evidence of atypias in this sample
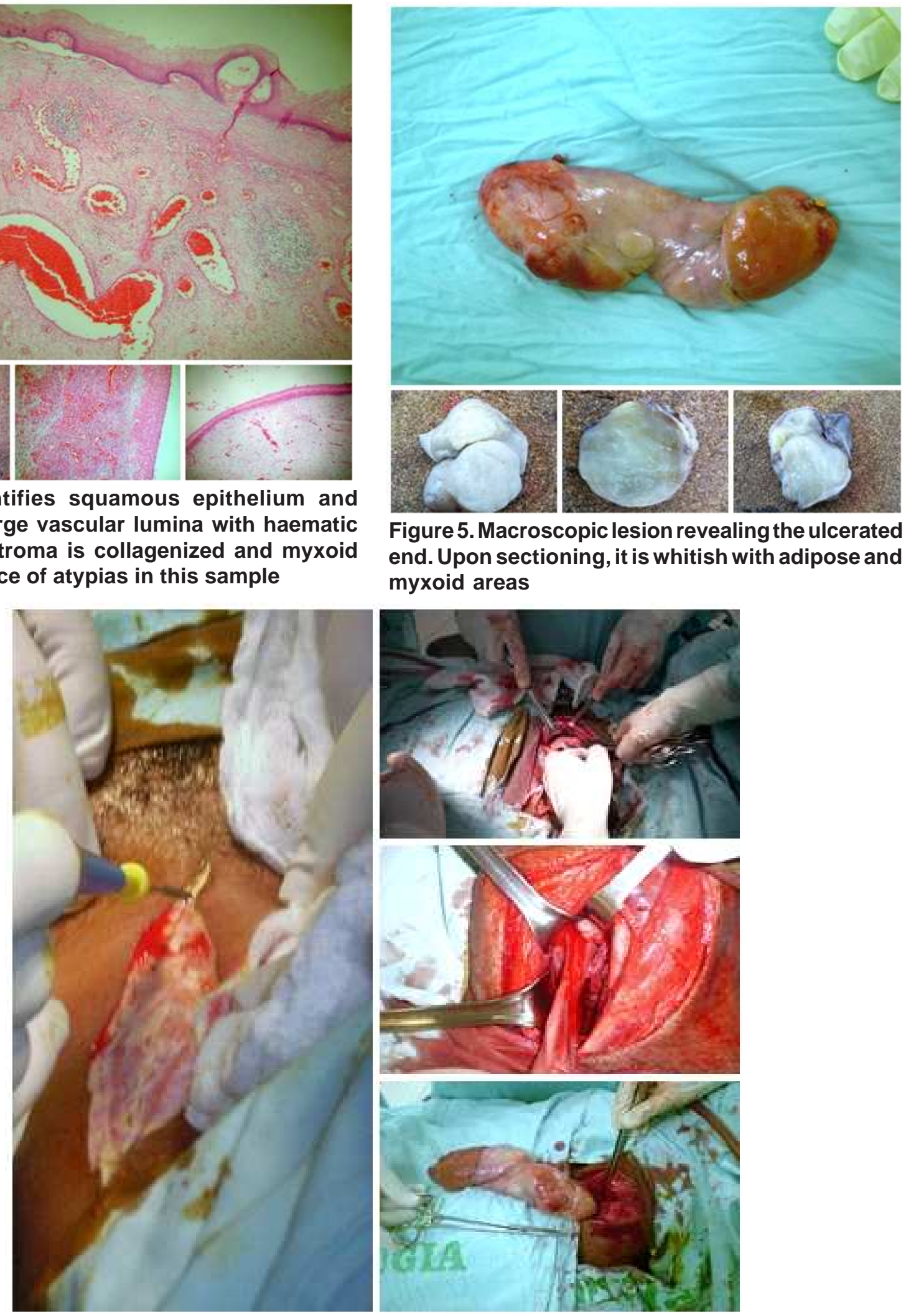

Figure 5. Macroscopic lesion revealing the ulcerated end. Upon sectioning, it is whitish with adipose and myxoid areas
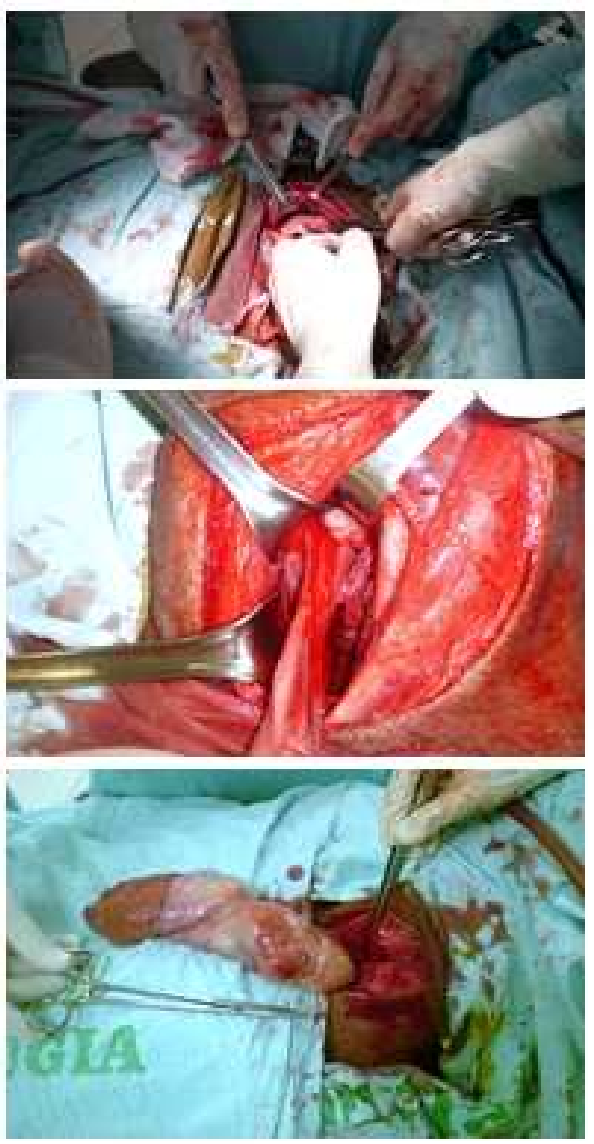

Figure 4. Left cervicotomy showing implantation pedicle of the esophageal lesion 


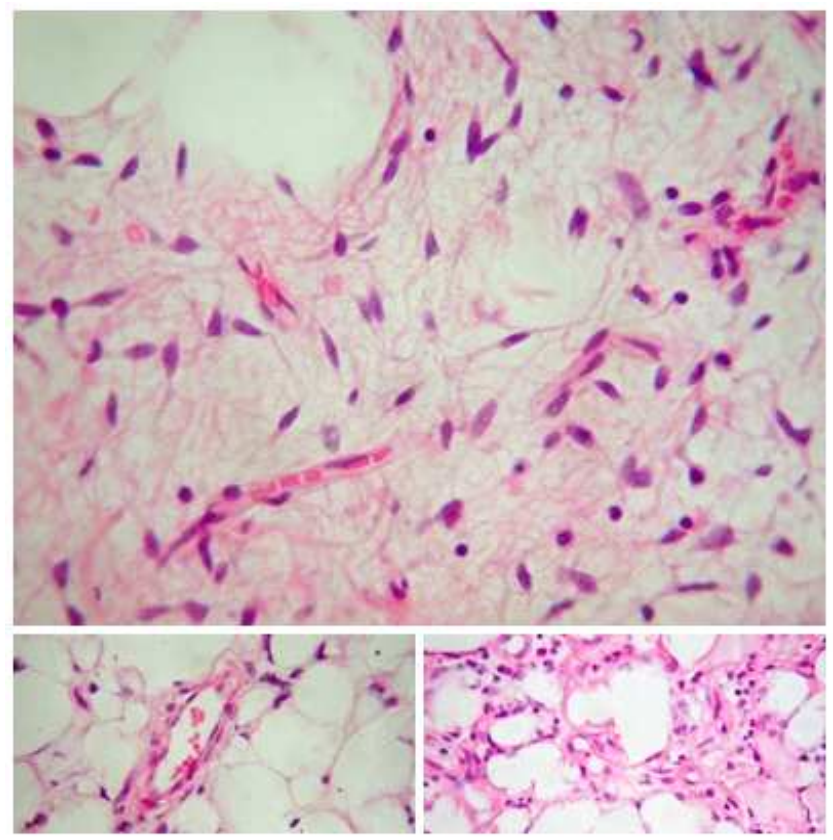

Figure 6. Malignant neoplastic lesion composed of a myxoid matrix, plexiform capillaries, and proliferating lipoblasts

Microscopically, we identified a malignant neoplastic lesion of mesenchymal origin, composed of a myxoid matrix with a plexiform capillary pattern and proliferating lipoblasts. It reveals a low mitotic index with focal necrotic areas and hemorrhaging (Figure 6).

\section{DISCUSSION}

In the five cases reported, until now, of myxoid liposarcoma located in the esophagus, the patients range between 49 and 68 years of age; our case is the first reported in a young patient (28 years of age $)^{3-5}$. Regarding gender, there is a female case ${ }^{5}$ and four male cases ${ }^{5}$, predominating in males, as in our case.

Recurrence has only been reported for one female gender case $e^{5}, 25$ months after the polypectomy; recurrence has not been reported for the male gender and after 12-month follow up, our patient had not relapsed.
The first case of myxoid liposarcoma in the esophagus described in the literature refers to $1983^{4}$ and the most recent refers to $1997^{5}$. In Colombia, this is the first case documented and the sixth at world level, bearing in mind current bibliography reviewed.

The size of malignant neoplasias ranges between 12 and $4 \mathrm{~cm}$; our case is the biggest reported with a $20 \mathrm{~cm}$ longitudinal diameter ${ }^{5}$. It is common to find the histological type of myxoid liposarcoma in the cervical site and infrequent in the distal region of the esophagus. The transmural involvement in this histological type has not been reported until now.

Surgery is the treatment of choice; in these cases, polypectomy is the procedure of choice, which was performed in the five cases reported previously ${ }^{3-5}$ and was the procedure carried out with our patient.

\section{CONCLUSION}

The histological diagnosis is the basis for treatment and prognosis of these patients; given that myxoid liposarcoma is highly uncommon, frequently benign neoplasms are considered with small biopsies.

Although in these cases the initial biopsies may suppose benign lesions, only after the histological processing of the whole specimen can we conclude the diagnosis of myxoid liposarcoma.

\section{REFERENCES}

1. Minutolo V, Rinzivillo C, Li Destri G, Scilletta B, Cammisuli F, Puleo S. Giant esophageal polyp: a rare and benign neoplasm. Chir Ital. 1999; 51: 313-6.

2. Weiang G, Knipping L, Mangold G. Fibrovascular esophageal polyp: diagnosis and therapy. Der Chirurg. 2001; 72: 847-52.

3. Chung JJ, Kim MJ, Kim JH, Lee JT, Yoo HS, Kim KW. Imaging findings of giant liposarcoma of the esophagus. Yonsei Med J. 2003; 44: 715-8.

4. García M, Buitrago E, Bejarano PA, Casillas J. Large esophageal liposarcoma. Arch Pathol Lab Med. 2004; 128: 922-5.

5. Liakakos TD, Troupis TG, Tzathas Ch, Spirou K, Nikolau I, Ladas S, et al. Primary liposarcoma of esophagus: A case report. World J Gastroenterol. 2006; 12: 1149-52. 